Kom, 2019, vol. VIII (3) : 65-79

UDC: 28-1 Мула Садра Ширази

14 Мула Садра Ширази

DOI: $10.5937 /$ kom 1903065 A

Original scientific paper

\title{
The Essence of Faith \\ in Mulla Sadra's Philosophical Thought
}

\author{
Amanallah Alizadeh \\ Faculty of Philosophy, Al-Mustafa International University, \\ Qom, I. R. Iran
}

The present writing is trying to explain the essence of Faith in Mulla Sadra's philosophical thought. Firstly, I will deal with religious teachings that recall universally human beings to go toward belief which is introduced as the purpose of man's creation and positive responds to revelation. Then, the nature of faith will be discussed - whether it is a type of knowledge or it is merely a heartfelt confession. Finally, the paper will talk about degrees of faith and relationship between faith and intellectual perfection from one side and virtuous action and spiritual sates from another side.

Keywords: faith, essence, Islamic philosophy, Islam, Mulla Sadra, Quran

\section{Introduction}

O you who have believed, believe in Allah and His Messenger!

(Quran 4: 136)

The Quran recalls human beings repeatedly and in different verses to go toward faith. It sometime says: "O Mankind! The Messenger has come to you with the truth from your Lord, so believe; it is better for you..." (4: 170). And sometimes the Quran encourages us: who you have believed, shall I guide you to a transaction that will save you from a painful punishment? In some verses the Quran gives glad tiding to mankind: "Unquestionably, \{for $\}$ the allies of Allah there will be no fear concerning them, nor will they grieve" (10: 11). Or says: "Certainly will the believers have succeeded" (23: 18).

Corresponding author: alizadehamanallah@gmail.com 
All these verses and hundreds of other verses introduce salvation of mankind through having faith. Almighty God directly or indirectly invites human beings to be faithful, which leads to salvation, transaction and rescue of mankind from sadness and sorrow. There are also other types of God's addresses in the Quran that invite believers toward faith when He says: "O you who have believed, believe in Allah and His Messenger" (4: 136). The address of almighty God in this verse is somehow different from the abovementioned ones. It seems that God almighty is not satisfied to be merely believer, rather He recalls human beings to go to deeper layers of faith and achieve higher level of perfection.

The infallible Imams, who are the real interpreters of Quran and revelation, also invite and encourage us toward faith. For example, Imam Ali ibn Abi Talib in sermon 110 of Nahj al-Balaghah declares that:

The best thing, that believers are resorting to God, is belief to Allah, His Messenger and doing Jihad (Sayyid Radiy 1999: sermon 110-106).

Imam al-Sadiq also in his dialogue with Husain Ibn Naeem Safee said:

The God almighty sent His Messengers to invited people to believe in God (Al-Kulayni 1990: IV/145).

In this declaration, Imam al-Sadiq introduces faith as a purpose of sending prophets to mankind. Those who accept the invitation and become believers will not only achieve salvation and rescue from sorrow but also, become benefactors / benefactresses among human beings and all existents. Prophet Muhammad ibn Abdullah says about goodness and blessing of believers:

Believers are the origin of benefit. If you become their companions, they will give you benefits. If you consult with them, they will give you advantages and if you enter into partnership with them, they would be beneficial. Everything they do have benefits (Ayandeh 2003: 782).

Now the questions which arise here are: what is the faith that the Quran invites all mankind toward it? What is its reality that interpreters, translators of revelation consider as a purpose of sending prophets and cause closeness of mankind to Allah? What is the belief that introduces believers as a saved and rescued man from sorrow and sadness? What is its essence which progresses human beings from the level of animals to the closest position to almighty God. (A man comes close to Allah like two sides of a bow in arciform and hemicycle). 
Therefore, it is necessary to do research about it to give answers to the abovementioned questions. Because, it is significant for us as human beings to know about faith that is introduced as a purpose of creation, target of sending prophets toward mankind and best instrument that brings mankind close to God. So, it deserves to be discussed and it is vital that the essence of faith should be cleared. Since Mulla Sadra is one of the most influential Islamic philosophers and mystics, I will try to explain the essence of faith from his perspective.

\section{The Essence of Faith in Mulla Sadra's Thought}

The faith is a Quranic term that does not have clear logical definition like many other Quranic terms. Because it is not the Quranic method to explain words or expressions directly and logically, rather the Quran describes to disclose the reality of something or brings examples to make it clear. Mulla Sadra takes this method and suffices to mention lexical meaning briefly:

The Iman (faith) is derived from Amana in Arabic language and its verbal paradigm is If'al. When it is used as transitive verb, it means acknowledgement. It seems that mu'mineen (believers) are call so, because they are saved from opposition and refutation. When it becomes as transitive verb by the word of B in Arabic language, it means confession. Sometime it is used for trust and reliance. Both of confession and reliance are used truly in verse of Quran when says: those who believe on the invisible world (Mulla Sadra Shirazi 1987: I/254).

There are numerous opinions about technical meaning of faith. The diversity of opinion referring to essence of faith, traces back to the time of descending the Quran. Khawarij was a sect of Muslims, excommunicated by other Muslims, who commit "mortal sin". They even excommunicated Imam Ali's followers based on that criteria and killed them. Murji'ah, as another branch of Muslim, maintains that belief is sufficient to be a true Muslim. There is no necessity for action to be part of faith. This idea is something that is totally different from what Mu'tazila said. Because Mu'tazila maintains that action is part of belief and has a great role in it. It differs from Ahl al-Hadith (who believe that the only way to understand Quran is narration) who combined faith from there elements; confirming by heart, confessing by language and acting by organs (Rezazade Judi 2005: 45).

Mulla Sadra's sayings regarding the essence of faith are different, but are not opposite to each other. Sometime he introduces it as divine blessing and emanation, but sometimes he introduces it as knowledge, wisdom and 
principles of Sharia. In his book Asrar al-Ayat he introduces faith as divine blessing that encompasses lonely believers:

The knowledge of monotheism and true faith is a light that God luminesces to heart of those that God wishes. This light is not obtainable by testation or by discussion or combination of arguments as it is habituation of arrogance-scholars. Many of those, who apparently seem Muslims, are infidels and inner impiety... the true Muslims are those who believe on almighty God and the day of resurrection. To obtain of such doctrines is worthy and excellence in its own type that are unattainable by quoting of narration or memorizing of others saying (Mulla Sadra Shirazi 1980: 11-12).

You see Mulla Sadra introduces a true believer as a man who obtained luminaries from almighty God. These luminaries are divine blessings that are unattainable without God's endowment, but those who obtained such a gift, obtained honor and Excellency. Mulla Sadra continues his discussion and mentions that this divine blessing causes human perfection and a stepby-step guide from immaturity and defection towards the pinnacle perfection and possessions. He evokes a Quranic verse that says: this luminary causes departure of mankind from a dark and gloomy world toward perfection. Therefore, he explicitly expresses:

Verses of Quran indicate that faith is an intellectual luminary that causes departure of human soul from potentiality, defection toward actuality and perfection and promotes the soul from corporal and dark world toward spiritual and enlightenment world. It Prepares human soul to join Allah's... and discovers the essence of things as they are (Ibid.: 28-29).

We should consider that there is no contradiction between divine blessing of faith and its willingness of faith for human beings; because it seems apparently contradictory to accept voluntarily faith and its God's endowment. If it is divine blessing, then, it won't be voluntary. We would be obliged to go toward faith without any free will to select the belief. Thus, it is not compulsory, rather our eagerness and hot-heartedness toward offspring of bounty and luminaries prepare a situation to obtain God's grace and blessings, that is to say, the desire of mankind toward Allah compensates his / her free will. Moving toward luminary to join with Allah discloses the essence of every existent. In his point of view, infidelity is located on the opposite side. Mankind would go toward aberration, which is the most mortal sin and painful torture, without knowledge and wisdom. Up to now, we recognized 
that Mulla Sadra ties the faith with religious doctrines and divine knowledge and puts aside infidelity and aberration that are considered a deviation from the right path. Mulla Sadra explicitly says:

You should know that the offspring of severe and painful torture is infidelity and it is a type of ignorance and darkness. It is not only the simple ignorance, but also it is an accumulated ignorance that is combined with beliefs, self-pride and animosity (Ibid.: 6).

When Mulla Sadra mentions different opinions about essence of belief in his interpretation of the Quran, he quotes a famous narration from Imam Ali ibn Abi Talib who said:

The faith is acknowledging by heart, confessing by tongue and acting by organs. (Mulla Sadra Shirazi 1987: I/245).

However, he himself categorized faith and prophet's doctrines into three general groups when he talks about the essence of faith:

You should know that faith and other religious teachings of prophet exclusively limited to three general categories: A) doctrines, B) Spiritual States, C) Action. The doctrines are basic teachings of religions that lead to the spiritual states that in its turn lead to an action. The purpose of knowledge and divine science that is stated in here is to know about God, attributes, His actions, divine book, His messengers, and judgment day. The aim of Spiritual State is to separate our soul from pollution, such as voluptuousness, irascibility, love of power and this world, but the target of action is to perform obligations that Allah ordered and to leave inviolable things that God has forbidden (Ibid.: I/249).

After the abovementioned explanation, he begins to analyze and answer these questions: which one of these three affairs (doctrines, spiritual states and action) has superiority over others - doctrines, spiritual states or action? Are they parts of belief? Doesn't it mean that actions are not part of faith when in the Quran we read:

Indeed, those who believe and do righteous deeds and establish prayer and give zakah will have their reward with their Lord, and there will be no fear concerning them, nor will they grieve

(Quran 2: 277); 
Or:

And give good tidings to those who believe and do righteous deeds that they will have gardens [in Paradise] beneath which rivers flow.

Whenever they are provided with a provision of fruit therefrom, they will say: "This is what we were provided with before". And it is given to them in likeness. And they will have therein purified spouses, and they will abide therein eternally (Quran 2: 25).

If action is part of faith, so there is no need to add action after faith. Since almighty God adds action after faith in many Quranic verses, it seems that action is part of belief. Mulla Sadra did not reply to this question directly, but he replies to it through analysing mankind and explains three types of individuals; the first type of individuals are those who obtain their knowledge via five senses. The action is very important for them. They are in the lowest level of understanding. The second type are those who follow the reason. Action for this group is merely for rectifying their soul. The third type of people are those who are focused on their spiritual dimensions. They are placed in the middle stage of the two groups. In his anthropology, Mulla Sadra classifies individuals as follow:

For those, whose understandings are in level of five senses, action is better than knowledge and spiritual states, but for those, who are followers of reason and obtained knowledge from offspring of prophet-hood, divine science is better than spiritual states that prefer spiritual states than action... [Finally, he concludes that] the base for faith is to know paradise, but the validity of action by our organs is for this reason to rectify our soul and purify our internal faculties that need to perform good actions and left bad actions. (Mulla Sadra 1987: I/249-252).

He also has a nice paragraph regarding this issue to illustrate the main pillar of faith when he interprets the verse 285 of "Al-Baqara" chapter (surah). There, he maintains that the pillar for faith is knowledge and religious teachings. Action is a subordinated thing. He clearly says:

There is no action as a part of faith while we define believers, except the true knowledge. Thus, if divine science truly descended to inner part of mankind without conducts, either good or bad, the man would be a believer truly and would achieve beauty and happiness without any negligence and deficiency in his/her belief... Although it was merely a supposition, its purpose was to inform this point that the knowledge and 
doctrine are the base and action is its subordinate (Mulla Sadra Shirazi 1980: I/4).

Mulla Sadra considers that cleanliness and purity of spirit, which causes mankind to be in the exposure of the divine dispensation and intellectual luminary, is that soul be free from foul situations and abstain from doing wrong things. Although being free from foul situation or abstaining from doing wrong things prepare a situation for faith and obtaining intellectual luminary, they are not faith; because these two are not considered man's perfection:

The external purity and internal purity of soul are not actually a man's perfection, because external purity is non-existential. The non-existential issue is not perfection, rather cleanliness of soul means that the light of faith shines on spirit, that is to say, the light of faith means getting the knowledge about Allah, His action, holy scripture, messengers and resurrection days (Mulla Sadra 1981: IX/139-140).

Now, we comprehend that Mulla Sadra has various explanations of faith which do not contradict each other; because he illustrates one reality in different ways. Talking about intellectual luminary, divine blessing, knowledge and cognition discloses many aspects of one truth. Based on his point of view, external and internal purity of soul have refining and dust-removal role that prepare conditions for intellectual luminary and human perfection of man. The Man with this intellectual luminary knows the essence of everything. Mulla Sadra named that wisdom or philosophy. From his perspective, wisdom, philosophy, faith, and knowledge about God, His attributes and etc... are synonyms for each other. In his book Mafatih al-Ghayb, he said:

Indeed, the spirit of mankind departs from potentiality toward actuality and perfection and would possess good life by drinking the water of immortality which is wisdom and philosophy. Anyone who attains philosophy would obtain goodness and Excellency (Mulla Sadra Shirazi 1984: 275).

Thus, wisdom, philosophy in its particular meaning, and faith and intellectual luminary have the same reality, but the difference between them refers to language to explain. Because, like faith and intellectual luminary which permits us to realize reality of things as they are, wisdom and philosophy also allow us to recognize things as they are (Ibid.: 137). He declared precisely at the beginning of al-Asfar: 
Philosophy and wisdom are perfection of human's soul through obtaining knowledge about the essence of existents as they are... in this way man becomes like Allah (in two things): in perfect encompassment of objects and freedom from corporeality... (Mulla Sadra Shirazi 1981: I/137).

Of course, you should consider that when Mulla Sadra compares philosophy to faith or makes relationship between the two, he does not aim at all types of philosophy. He aims at the philosophy that leads to perfection of human beings. Man, by obtaining knowledge from the essence of existents, becomes like God for his/her perfect-encompassment and for freedom from corporeality; because mankind obtains existential-expansion by learning and grasping knowledge which is an existential thing in its type. In volume 6 of al-Asfar al-Arbaiah, he said:

Not only an existence is a truth that flows in all existents in different kinds and levels, but also attributes of existence like knowledge, power, will and life flow to all existents (Mulla Sadra 1981: VI/117).

It means that just like existence flows in analogical gradation to all existents, the attributes of existence also flow in a gradual way to all existents; because Mulla Sadra believes in "fundamental reality of existence" (Asalat al-wujud), he cannot put knowledge out of existence. The meaning of fundamental reality of existence is that existence fills all existents and there is nothing out of existence. Thus, knowledge cannot be out of existence, rather it is a type of existence. He explicitly declares:

The knowledge is a type of existence. If you ask about reality of knowledge, we can say that they are both equal and coextensive. Whenever existence locates in lower position that comes close to weakness and non-existence, it becomes deprived of knowledge and understanding. It does not mean that there is no any type of knowledge at this level of existence; rather it means that it does not have a higher level of knowledge. The corporeal existents, because of weakness in their existence, not only disables the possession of knowledge regarding other existents, but also disables the knowledge about their parts and gradients (Ibid.: VI/149).

Now that we have proved that "knowledge" is not only a type of existence but also an equal to existence, it is also inevitable to confess that anyone who obtains more knowledge, would help himself/herself to expand his or her existence. Whosoever wants to have existential expansion, must go toward 
knowledge and cognition. With knowledge, man can move from potentiality and poverty toward actuality and richness. With knowledge man becomes empowered. This knowledge, which is considered a type of existence, is equal to philosophy. Mulla Sadra maintains in the introduction of his book Asrar al-Ayat that the salvation and happiness of mankind is achievable by obtaining true philosophy which deals with knowledge of Allah and his actions, attributes and resurrection day. Let's see his exact statement in this regard:

The origin of all happiness and goodness is to grasp true philosophy which is obtaining knowledge about Allah, His attributes, His acts, kingdom of God, resurrection and spiritual station of afterlife. This is the true faith and considered as great goodness and grace. Infidelity and deviation stands opposite of that (Mulla Sadra 1980: 2-3).

He, Mulla Sadra, in his interpretation of the Quran, counts a level of man's perfection as Intellect (human cognitive faculty) that is synonym with faith in Sharia usage. When he states the evolution of cognitive faculty, he defined the first stage of intellect as "intellectus potentials" or "intellectus material" and the last stage of intellect as "acquired intellect" because it utilizes from the "active intellect". A man, who achieves balance in his/her action and spiritual status, will be able to unite with active intellect. If he/she arrives into balance in actions and spiritual status, he or she will be believer. Here is his a clear explanation in connection with this:

The other name for intellect among divine wisdoms and monotheist philosophers, not among physicians, mathematicians, astronomers, is "active intellect" because it is far away for the second group of scholars to obtain, but philosophers utilize the active intellect for one stage of many stages of soul. Soul has many stages which include from potential state up to ultimate stage of soul which is called "intellect". The final stage of soul which is called "intellect" is synonymous with "faith" in Sharia (Mulla Sadra 1987: I/263).

Based on Mulla Sadra's point of view, faith and intellect are synonyms. Sometimes he names this stage of cognitive facility, intellectual luminary, divine blessing, and philosophy in metaphorical terms and divine wisdom. They are different expressions from different approach about one reality. Mankind by mortification and observation becomes eligible to know the reality of existents and recognize essence to existents. Thus, the true Philosophy or true beliefs are two names and terms for one reality. In this situation, philosophy and faith stand beside each other. Practical actions and purifying 
inner faculties have the role of luminosity for soul; because the soul needs external and eternal purification in order to obtain knowledge from active intellect to know reality of objects. As a result of such preparation, human beings deserve to be in exposure of active intellect.

\section{Degrees of Faith}

The effort that has been made to clarify faith in Mulla Sadra's point of view, paved the way for understanding the degrees of faith; because, Mulla Sadra returns faith to knowledge. In fact, he considers faith as a final stage of improvement for intellect. He names the final stage of cognitive facility faith that improved and became eligible to receive divine blessing and knowledge from active intellect. He maintains that if we accepted faith as a type of cognition, it would be easy to admit degrees for faith. Thus, for improvement of intellect, we need preparation of soul. Sharia teachings and morality doctrines have the role of purifying soul. In other words, our actions based on Sharia teachings and our balance in spiritual dimensions based on morality, purify our soul to be eligible for receiving knowledge. Since individuals vary in their external and internal purity which helps man to brighten their soul and receive divine's blessing, faith of individuals would be different. We may not fine even two persons to be equal in external and internal purity. Thus, people surely differ from each other in their faith because of their diversity in external and internal purities. Relating to this issue, Mulla Sadra gives a clear definition in his book:

Faith is "gradation-word" that has different meanings. Due to its intensity and weakness, perfection and defect, it would have various meanings. Some of these meanings are original and some of them are metaphorical, some of them are esoteric and some of them are exoteric. As some mystics said: faith is divided into kernel of the kernel, cortex and the cortex of cortex. The division of faith into these three levels is exactly the same as human being into degrees. Faith is one level of man's position in his or her humanity (Ibid.: I/254).

Now, for better understanding, I will try to continue my investigation and present these questions: why is the word faith a "gradation-word" that applies to different examples? What factors interpose in gradation of faith? What degree is called a true faith and what level is called metaphorical?

In order to make clearer the way of understanding true faith from Mulla Sadra's notion, we need to answer the above questions in this section; because we would attain the nature of belief, in that case. Mulla Sadra divides 
faith into imitation and audible, intuitive and heartfelt faith. He has a nice statement related to the second type of faith, intuitive:

Intuitive faith and heartfelt faith is the faith obtained by the divine luminary that brightens the heart and soul... By this faith, things are discovered as they are and it is disclosed that everything originates from almighty God and finally returns to Him. These groups of people are Near-stationed the God. Some of these Near-stationed the God are those who are called "outstrippers" (al-Muqarrabeen). Then, there are those believers who stand behind them because of their differences in beliefs and cognition they have regarding almighty God, His attributes and His action. The degrees of theosophists (mystics) are infinitely different because the encompassment of God's essence is impossible and the ocean of cognition regarding Allah doesn't have a side. Thus, everyone would be at the level of cognition that they obtain (Ibid.: I/28).

He clearly says that those believers who have intuitive faith have different degrees in faith because of their diversities in cognition. Whoever has more cognition and knowledge will have a higher level of belief and position. Since cognition and actions of individuals are dissimilar, faith, which is defined as intellectual luminary, divine blessing, true philosophy or knowledge about essence of existents, is diverse, namely the degrees of faith relate to degrees of cognitions. Those who have more access to knowledge and cognition and improve their intellectual faculty, are those who have achieved more perfection and received faith. Whoever is deprived of knowledge remains in potential intellect and hasn't purified his/her soul, has remained on lower level of belief and perfection. In the second volume of interpretation of the Quran, Mulla Sadra explained degrees of faith and reasons for differences:

Every one of faith and infidelity has intensity and weakness, because faith is heart-felt luminary that has intensity and weakness. The lowest level of faith is the faith, which does not initiate from insight or intuition, rather it initiates from imitation. The highest level of faith is the faith which initiates from cognitive-certainty (Ilm al-Yaqeen), certainty of direct vision (Ayn al-Yaqeen), the origin of and absolute experienced certainty (Haq al-Yaqeen) (Ibid.: II/177).

The abovementioned paragraph clearly shows that there is a close relationship between cognition, purification and faith. Whoever has done external and internal purification, he or she will obtain more intellectual luminary and would have more faith. Exterior and interior purification provide more 
conditions for intellectual luminary and faith. The condition for obtaining intellect luminary and faith would be ready; because the cognitive faculty of human being will easily come out from maturity if the soul is purified. It easily receives knowledge for its eligibility. In this case, the progress of intellect from potential to actual and from there to acquired intellect would be an easy task. A man would reach true faith without any serious problems. In this circumstance, a man who obtains intellectual luminary and faith in this world, would also able to see the essence of existents in this mundane world and could use it as a light-way instrument for hereafter. Thus, it becomes clear that people differ in their faith from each other; because of their differentiation in actions, spiritual states and cognition. As people have different types of cognition, action and spiritual states, they would have different faith.

There are some who might criticize us whether Mulla Sadra categorized degrees of faith in four levels or three levels. To reply to this question we can say that Mulla Sadra mentioned three or four levels of faith in his book to illustrate the three or four important levels of faith, otherwise he believes in plenteous degrees of faith. He said the same things on existential degrees of human being:

There are different levels and degrees of human beings. Some of them are physical and some of them are spiritual and some others are intellectual. Every one of these three existential levels of human being has infinite imaginative degrees (Mulla Sadra 1981: IX/96-97).

Since human being has infinite existential degrees, he or she will have different degrees in faith. If it is imaginable to classify man in physical, spiritual and intellectual levels, it is imaginable to categorize faith; because man expands his/her existential aspects by knowledge. According to the level of his knowledge and progress, he/she will obtain faith and belief. Mulla Sadra restricted levels of faith into three degrees of physical, spiritual and intellectual to merely classify faith into important classification. To do so, he generally categorized faith into degrees. Once, he classified it into three degrees and then, from another aspect, into four levels. For instance, when he talks about levels of faith in volume 7 of Tafsir al-Quran al-Karim, he mentions three levels of faith. He primarily says:

Faith has three levels: populace, particular (lovers) and more particular (loved)... There are particular knowledge and action for every one of these three levels. The knowledge for the first group is to accept what prophet Muhammad brought and to believe heartily in the invisible world and what prophet said, but from the practical aspect, they must do 
goodness and avoid badness and crimes to be eligible to receive rewards and be away from punishment. The particular level of faith (lovers) from scientific aspect is to believe on God, angels, holy books, prophets and God's saints, resurrection, hell and heaven and obtain knowledge through clear reasons and divine principles to these doctrines. The third level, which is called more particular (loved), is to manifest God through His greatness and magnitude attributes to man which remove obstacles and barriers for man (Mulla Sadra 1987: VII/158-160).

Finally, in his book he mentions that faith at the first level is invisible (Ghaybi), at the second level is objective (Ayni) and the third one is called clearness (Ayani). For instance, the ascent of the holy prophet to heaven up to Lote Tree of the Limit (Sadrat al-Muntaha) was clearness faith, but the prophet passed this level by God's chrism up to have complete intuition and receive clearness faith. Based on Mulla Sadra's point of view, there are clear examples of three levels of faith. The final level of faith is the clearness that our prophet experienced at the night of Ascent to heaven; but Mulla Sadra has another classification in volume 6 of Tafsir al-Quran al-Karim which names four degrees of faith that begin from lingual confession to ultimate degrees obtainable by lonely God's saints and mystics:

The first stage of faith is that man confesses the testimony by his/ her tongue, but he might be neglectful for the meaning of faith or even be hypocrite at heart to that and refuse it. The advantage of such belief is that man would save his/her blood, properties and could have his/her children considered as Muslims (Ibid.: VI/231; I/255).

He continues his explanation referring to the second level of faith and explicitly declares, and writes that the second stage of faith is that a person confesses the testimony, knows the meaning of testimony and all necessities of religion. Although it is not a certain belief to give us true knowledge connecting to things, it can be an offspring of good actions and in its turn it can be the origin for obtaining a certain knowledge that save us from painful punishment in hereafter. This type of belief has the capacity for replying many dubious things; however, Mulla Sadra considers this type of belief for common people and theologians, because it is not an intuitive and heartfelt belief.

He introduces the third level of faith that is beyond the second grade. Believers at this level do not only confess, know the meaning of testimony but also achieve reality and mysteries of things. This is a particular faith that is given to a specific group of people who obtain that through intuition. Mulla Sadra maintains that the third grade of faith is for those believers who not 
only confess by language, know the meaning of testimony but also achieve the realities of existents, visible world and celestial world. This is allocated to transcendental philosophers who passed the level of words, meanings and achieved reality by reason and intuition (Ibid.).

The fourth level is the final stage of belief at which believers finalize their spiritual journey. Mulla Sadra introduces it for particular group of believers who successfully pass three levels of faith. He donates this type of belief to God's saints and theosophists who have strengthened by both arguments and intuitions. Moreover, they achieved reality by reason and intuition. $\mathrm{He}$ clearly said in his Tafsir that the fourth level of faith, which finalizes the journey of believers, is donated to Kummaleen of mystics, theosophists and saints who submerged in divine unity and cannot see anything else. This level of belief is unachievable in this mundane world except for particular mystics and God's saints.

The abovementioned levels of faith categorized by Mulla Sadra in his books do not mean that he restricted degrees of belief in three or four levels; because, as it was mentioned previously, faith relates to actions and spiritual states of man. Actions and spiritual states of individuals are different so, the layers of faith of people surely differ from each other. It is almost impossible to find two people equal in their deeds, morality and cognition. As a result, everyone's beliefs differ from other people's. By considering these two primary steps we prepare a situation for soul to progress. Mulla Sadra has a nice association for levels of faith. He compares four levels of faith to walnut, which begins from the lower layer of walnut to its kernel and oil.

\section{Conclusion}

To conclude, faith in Mulla Sadra's point of view is a type of cognition and knowledge about God, His names, His attributes and His actions. It is a kind of submission to divine message and messengers and it is a wisdom and philosophy that brings mankind toward perfection to see the reality of existents. It is also called intellectual luminary that provides insight into our mind, after our soul is purified from evil. It is difficult to find even two people who have completely the same knowledge and action. Thus, everyone has unique faith because of his/her particular knowledge and action. The classification of belief into three or four groups by Mulla Sadra does not mean that faith has only these categories and levels; rather, it means that he classified it to be understood easily. So, he classified belief into imitative and intuitive faith once and populace faith, particular faith and more-particular in second or sometimes he classified it into four groups and started from merely lingual-testimony to confession by tongue and heart. Then, it contin- 
ues to intuitive faith which refers to transcendental philosophers. The final stage of faith belongs to those believers who submerged into divine unity predisposed to God's saints and mystics. This is achievable for every man in this material world to move step by step toward perfection.

Received: September 9 $9^{\text {th }}, 2019$.

Accepted: November $15^{\text {th }}, 2019$.

\section{References}

The Holy Quran.

Al-Kulayni, Muhammad ibn Ya'qub (1990), Usul al-Kafi, translated by Jawad Mustafawi, Tehran, Ilmiyya Islamiyya.

Ayandeh, Abul-Qasim (2003), Nahj al-Fasaha (Mađmu'e Kalamate Qesare Rasul Akram), Tehran, Donyaye Danesh.

Mulla Sadra Shirazi, Sadr al-Din Muhammad (1980), Asrar al-Ajat, introduction by Muhammad Khajawi, Tehran, Anjomane Hekmat va Falsafe.

Mulla Sadra Shirazi, Sadr al-Din Muhammad (1981), al-Hikma al-Mutáaliya fi al-Asfar al-Aqliyya al-Arba'a, Beirut, Daru Ihya at-Turas.

Mulla Sadra Shirazi, Sadr al-Din Muhammad (1984), Mafatih al-Ghayb, introduction by Muhammad Khajawi, Tehran, Tahqiqate Farhangi.

Mulla Sadra Shirazi, Sadr al-Din Muhammad (1987), Tafsir al-Quran al-Karim, introduction by Muhammad Khajawi, Qom, Bidar.

Rezazade Judi, Muhammad Kazim (2005), „Barresiye Moqayeseiye Iman az Negahe Mulla Sadra va Kierkegaard“, Ma’arefe Eslami 2 (1): 7-34.

Sayyid Radiy, Abul-Hasan Muhammad ibn Husein (1999), Nahj al-Balagha, Tehran, Elmi va Farhangi. 